allows himself to be manipulated by media and political pressures into touting spectacular results. The Hwang case could have been devastating for the field. Luckily, a new protagonist emerged, with results that were promising and reproducible. Japanese scientist Shinya Yamanaka restored the field's credibility with his careful work on induced pluripotent stem (iPS) cells - adult cells genetically reprogrammed to mimic natural stem cells capable of developing into any other type of cell, and which could potentially be used instead of human embryos. But because iPS cells emerged from work on human ES cells, the latter remain essential to understanding the biology of human tissue formation.

Park does not discuss how the politicization of regenerative medicine contributed to the popularity of stem-cell tourism and treatments of doubtful effectiveness. In this regard, oversight by the International Society for Stem Cell Research (www.isscr.org) in Deerfield, Illinois, is valuable. Bypassing sluggish governments, the society provides guidelines for how to design translational studies and informative tools to protect

\begin{tabular}{|c|c|}
\hline "Luckily, & deceptive adver- \\
\hline anew & tisements of stem \\
\hline protagonist & cell therapies. \\
\hline $\begin{array}{l}\text { emerged, } \\
\text { with results }\end{array}$ & $\begin{array}{l}\text { The book ends } \\
\text { with the White }\end{array}$ \\
\hline that were & House ceremony \\
\hline romising and, & on 9 March 2009 \\
\hline eproducible." & $\begin{array}{l}\text { at which Presic } \\
\text { Barack Oba }\end{array}$ \\
\hline
\end{tabular}
signed the executive order "Removing barriers to responsible scientific research involving human stem cells". Surprisingly, Park does not mention the still-unresolved Sherley v. Sebelius litigation, which, in August 2010, resulted in the US District Court for the District of Columbia passing an injunction to block the effect of Obama's decision on the basis that it violated the Dickey-Wicker Amendment. This April, the US Court of Appeals for the District of Columbia Circuit overturned that preliminary injunction, but the case is still open to further court decisions, arousing concerns among scientists and patients.

Nevertheless, The Stem Cell Hope is an instructive report about the negative effects of politics on regenerative medicine in the United States.

Gilberto Corbellini is professor of the history of medicine and bioethics at the Department of Surgical and Biotechnological Sciences, Sapienza University of Rome, Italy. e-mail: gilberto.corbellini@uniroma1.it
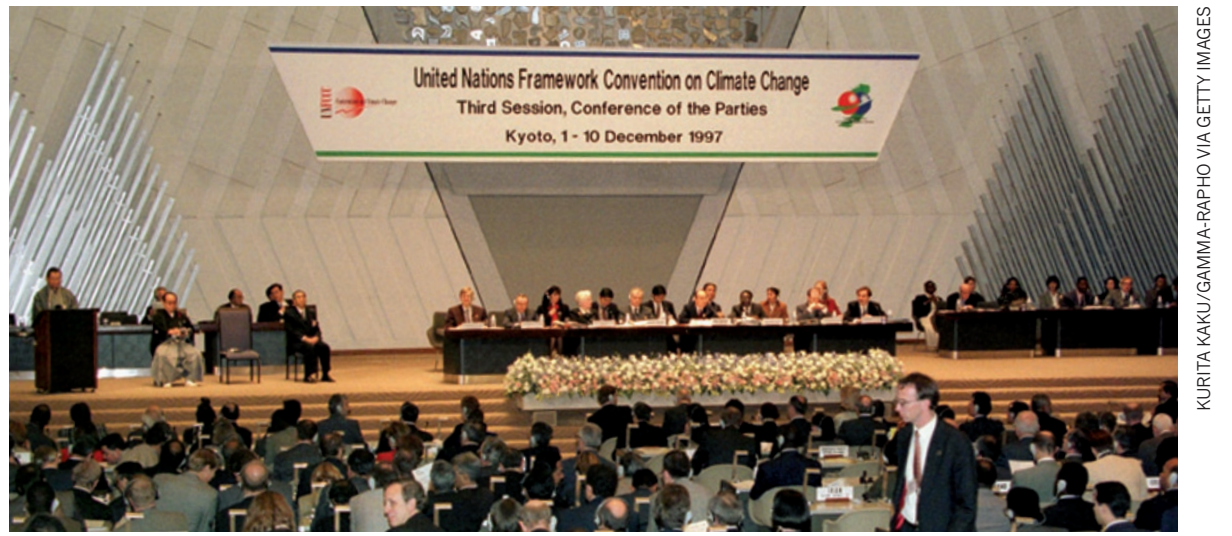

Many argue that the United Nations is ill-suited to controlling carbon emissions.

CLIMATE CHANGE

\section{Beyond Kyoto}

\section{Gwyn Prins commends the latest tome to advocate better ways to accelerate decarbonization.}

$\mathrm{T}$ There are omens and portents abroad. Not owls in the forum at midday, but spontaneous convergences of scholars of the history of human endeavours to reduce global warming. Among these, David Victor is an established expert. Global Warming Gridlock is a welcome addition to a rapidly growing set of perspectives on climate issues: on the causes of the crash of the 20-year Kyoto Protocol approach for tackling anthropogenic carbon emissions; and on possible and better alternatives. Together, these scholars are setting the stage for the next phase of global climate policies.

The change in the weather has been astonishing. When Steve Rayner and I suggested in Nature in October 2007 that the Kyoto Protocol should be ditched (Nature 449, 973-975; 2007) because it was doomed never to work and, furthermore, was licensed economic 'rent-seeking' - making money from taxpayers by promoting regulations but returning no value - the response was shock and much media attention. Nor were we alone; Victor's excellent earlier book, The Collapse of the Kyoto Protocol (Princeton University Press, 2001) was one trailblazer.

In Global Warming Gridlock, Victor rehearses why the

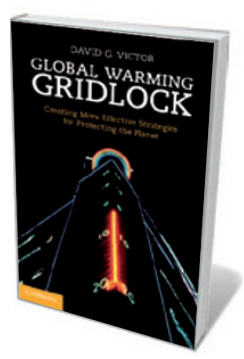

Global Warming Gridlock: Creating More Effective Strategies for Protecting the Planet DAVID G. VICTOR Cambridge University Press: 2011.392 pp. $£ 25, \$ 40$
United Nations is "ill-suited to take the starring role" because the actions of only a handful of countries really matter. He explains why a quest for legally binding agreements is futile, because it is guided by "lessons drawn from the wrong histories": from plausible but inappropriate analogies to treaties for well-defined ('tame') problems, whereas climate is a complex ('wicked') one. As Rayner and I explained in 2007 , Kyoto is basically a modified nuclear arms-control treaty. Victor agrees and adds new insights, such as the role of the 1970s quest for supersonic passenger flight, which gave rise to the Climate Impact Assessment methodologies so central to the Kyoto regime.

Today, such an analysis is no longer controversial. Even Yvo de Boer, former chairman of the UN Framework Convention on Climate Change, was making the case for Nationally Appropriate Mitigation Actions (NAMA) - or 'carbon clubs' as Victor calls them - at the COP16 meeting last December in Cancún, Mexico.

Victor's book went to press just before the Cancún meeting, and predicted more of very little progress. Yet Japan gave a historic lead by declaring that it would never subscribe to a second Kyoto commitment period, thus disproving one of Victor's suppositions that Japan would never have the guts to do this. And Russia and Canada joined Japan at the G8 Summit in Deauville, France, on 29 May 2011. Meanwhile, the United States confirmed that it would remain outside the treaty.

But at Cancún, a conjurer's trick was performed. Kyoto was dead on arrival, yet some groups - led by the European Union with the United Kingdom as cheerleader, and most of the developing world - argued 
that it was merely sleeping. Clever diplomats applied the equivalent of morticians' rouge. Nonetheless, it is now plain that, largely for reasons of the shifting geopolitical balance of power, the Kyoto model will not prevail.

Victor's broad approach chimes with that of Mike Hulme's 2009 book Why We Disagree about Climate Change and Roger Pielke Jr's The Climate Fix from 2010 - sadly not engaged in this volume. It also resonates with the Hartwell paper of May 2010, produced by a consortium of 14 scholars (including me), which is being used by several powerful parties as a template for the way ahead.

Victor explodes three myths. The scientists' myth is that research can determine 'safe' levels of global warming, whereas, as Victor puts it, "nothing that is really interesting to scientists lends itself to consensus". We are learning bitterly, from loss of public trust, the political costs of prematurely dogmatic statements about open-systems science.

The environmental diplomats' myth is that global warming poses a typical environmental problem and that Kyoto-type methods can attain a "mythical legal kingdom": because if it is the law, states obey. Right? Wrong, Victor explains. Furthermore, if governments are obsessed about compliance, they will be prone to under-promise. So it is far better to work from the bottom up with carbon clubs; with NAMA; and with a modern form of Japan's original (and current) 'pledge and review' approach, whereby the achievement of declared actions is checked before moving on.

The engineers' myth is that technological energy innovation will lead smoothly to implementation. Victor has a powerful and uncomfortable discussion of the traps here. Like Pielke, he concludes that electorates will not tolerate artificially raised energy prices. Like a widening consensus of his peers, he argues that governments will need to fund research, demonstration and development with low carbon taxes because the market is prone to blow corrupt bubbles. And Victor contends that it is smart to accrue 'co-benefits' from other popular actions - such as the Hartwell goals of increasing electricity access for the poor, first tackling non-carbon dioxide causes of warming and prioritizing adaptation.

Global Warming Gridlock boosts the case that there was always a better way. It is a valuable read but also tiring: Victor weaves his arguments back and forth like intricate tapestry. Although we wonks will work through it because it is worth it, most politicians and advocates probably won't, which is a pity. This is uncomfortable but essential reading.

Gwyn Prins is a research professor at the London School of Economics and Political Science, UK. e-mail:g.prins@lse.ac.uk

\section{Books in brief}

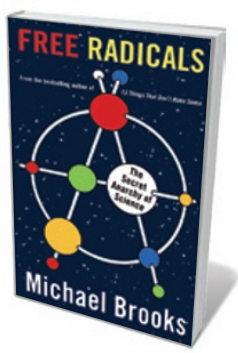

Free Radicals: The Secret Anarchy of Science

Michael Brooks PROFILE Books 288 pp. £12.99 (2011)

Scientists are complicit in painting their enterprise as arcane and inhuman, argues science writer Michael Brooks. As a result, the public is turned off. In reality, research is competitive, ruthless and anarchic. Some successful researchers are so driven to get their work into the public eye that they will pursue knowledge by any means - stealing ideas, taking drugs and following mystical beliefs. To regain respect from the public, scientists should rebrand themselves as dynamic explorers rather than docile knob-twiddlers, Brooks suggests.

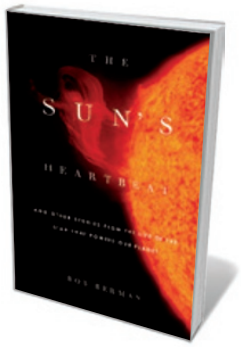

The Sun's Heartbeat: And Other Stories from the Life of the Star That Powers Our Planet

Bob Berman LITTLE, BRown 304 pp. $\$ 25.99$ (2011)

Astronomer Bob Berman admits that, like many of us, he used to take the Sun for granted. In his latest book, he puts our nearest star back firmly where it belongs, at the centre of our lives. He recounts witnessing eclipses around the globe, and describes the latest views of the solar furnace taken with advanced space probes that are revealing more about the Sun's birth and its eventual death. He covers solar cycles, the influence of the Sun on climate and human health, and the physics of fusion and magnetism.

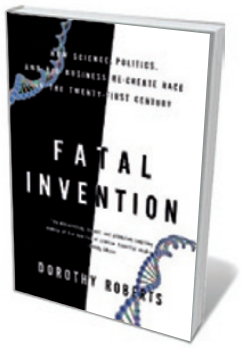

Fatal Invention: How Science, Politics, and Big Business Re-create Race in the Twenty-First Century

Dorothy Roberts NEW PRESS 400 pp. \$29.95 (2011)

Although it is not possible to genetically disentangle different races among humans, emerging biotechnologies are raising questions about how racial labels are used in medicine. In a provocative analysis of the emerging fields of personalized medicine, reproductive technologies, genetic genealogy and DNA databanks, law professor Dorothy Roberts warns that the science of genetics in the United States is at risk of being used to obscure racism in society.

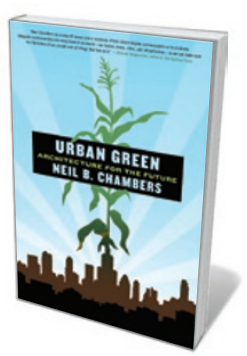

Urban Green: Architecture for the Future

Neil B. Chambers PALGRAVE MACMILLAN 256 pp. £18.99 (2011) Constructing sustainable buildings that reduce the impact of carbon emissions is a key goal for protecting the environment, but green alternatives that meet the needs of modern construction can be difficult to find. We should bring the architecture and conservation movements closer together by looking to nature for design ideas, argues green-building expert Neil Chambers. Oysters, for example, can filter water at up to 5 litres an hour; and mountains hold lessons for improving city layouts and building design.

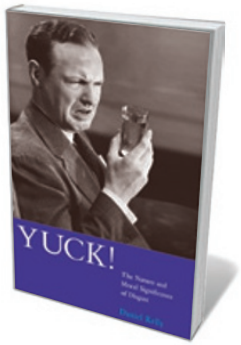

Yuck!: The Nature and Moral Significance of Disgust (Life \& Mind: Philosophical Issues in Biology \& Psychology)

Daniel Kelly MIT PRESS 208 pp. $\$ 30$ (2011)

From blood tofu to extreme political views, different people are disgusted by different things. Philosopher Daniel Kelly weaves together explanations for how physical and cognitive revulsion evolved - to protect us from poisons and parasites - and how they have since become attached to social mores. Because of the way our brains have evolved, he cautions that we should be wary of using gut reactions to make moral judgements. 